\title{
THE INFLUENCE OF DIETARY BORON SUPPLEMENTATION ON PERFORMANCE AND SOME PHYSIOLOGICAL PARAMETERS IN BANDARAH CHICKENS 2- LAYING PERIOD
}

\author{
Amina S. El-Saadany ${ }^{1}$; Effat Y. Shreif ${ }^{2}$; and Amal M. EL-Barbary ${ }^{1}$ \\ ${ }^{1}$ Dep. of Poult. Breeding Res. Anim. Prod. Res. Inst., Agric. Res. Center, Egypt \\ ${ }^{2}$ Dep. of Poult. Nutr. Res. Anim. Prod. Res. Inst., Agric. Res. Center, Egypt \\ Corresponding author: Amina El-saadany; E-mail: aelsaadany55@yahoo.com

Received:11/01/2017 Accepted:07/02/2017

\begin{abstract}
A total of one hundred hens and twenty cocks of Bandarah strain at 28 weeks of age were housed individually in single cages and distributed randomly among four treatment groups ( 25 hens and 5 cocks/ group) and the experiment ended at 44 wks of age. Birds in group1 were fed a basal diet and served as control group, the other three groups 2, 3 and 4 were fed a basal diet supplemented with 100, 200 and $300 \mathrm{mg}$ boron/ $\mathrm{kg}$ feed, respectively. Results indicated that supplemental boron to hens' diet had no significant effect on egg production, egg weight, egg mass, feed consumption and feed conversion compared with control group. Significant increases were observed for egg shell\%, shell thickness and Haugh units with increasing the boron level. While shape index, albumen and yolk percentages were not affected by treatments. Supplemental boron significantly increased egg shell calcium, phosphorus and boron concentrations. Moreover, plasma minerals $(\mathrm{Ca}, \mathrm{P}, \mathrm{Fe}$, $\mathrm{Cu}$ and $\mathrm{B}$ ) were significantly increased with the increase of boron level. Hematological parameters ( $\mathrm{Hb}, \mathrm{PCV}, \mathrm{RBCs}$ and $\mathrm{WBCs}$ ) were improved by addition boron to layer diets. There was a significant increase in plasma total protein, globulin, glucose and serum T3 resulted from dietary boron. Lipid profile and liver function significantly improved for boron treatments. Additionally, semen quality, fertility and hatchability percentages significantly improved with boron at different levels compared with control value. It can be concluded that boron supplementation to layer diets had a positive effect on plasma minerals $(\mathrm{Ca}, \mathrm{P}, \mathrm{Fe}, \mathrm{Cu}$ and $\mathrm{B}$ ) and egg shell (Ca, P and B). However, egg quality, reproductive and physiological status were improved. It is suggested that up to $300 \mathrm{mg}$ boron/ $\mathrm{kg}$ diet could be used in layer diets without any adverse effect on laying hens performance.
\end{abstract}

Key word: Boron- Laying hens- Minerals- Egg quality- Blood constituents- Fertility. 


\section{INTRODUCTION}

Boron, which bears the symbol $\mathrm{B}$ in the periodical table, is a semiconductive element with properties between that of a metal and a nonmetal (Kilic et al., 2009). This element is a chemically dynamic trace element that forms approximately 230 compounds, generally with other elements (World Health Organization, 1998; Kilic et al., 2009). Boron is released into the atmosphere from commercial uses, forest fires, coal combustion, and volcanoes. It reaches the ocean as a result of rock weathering, which constitutes another atmospheric source (Howe, 1998).

It is now known that boron is a necessary dietary component for humans and animals (Hunt, 1994; Nielsen, 1997; Kabu and Civelek, 2012). Boron meets most criteria as an essential nutrient (Hunt, 1998). It has a low atomic weight and binds to organic compounds in ways that influence biological function (Hunt, 1998). Moreover, boron having adjacent hydroxyl groups (transferases) has a tendency to form complexes with organic molecules. It may have an interaction with important biological substances, containing polysaccharides, pyridoxine, riboflavin, dehydroascorbic acid, and the pyridine nucleotides (Samman et al., 1998; Deviran and Volpe, 2003).

Boron has an essential function that regulates parahormone activity (McDowell, 1992) and therefore, effects of $\mathrm{Ca}, \mathrm{P}, \mathrm{Mg}$ and cholecalciferol metabolism (Miljkovic et al., 2004; and Kurtoglu et al., 2001, 2005). Whereas, Cufadar et al. (2011) indicated that dietary boron supplementation has positive effects on mineral balance, and therefore improving egg shell breaking strength and bone strength parameters in aged laying hens. Several studies have indicated that $\mathrm{B}$ is an important mineral for egg weight and egg shell quality in laying hens (Qin and Klandorf, 1991; Wilson and Ruszler, 1996, 1998). Eren et al. (2004) investigated that dietary B supplementation $(0,10,50,100,200$ and $400 \mathrm{mg} / \mathrm{kg}$ diet $)$ affected on egg production, interior and exterior egg quality in laying hens. Additionally, Yesilbag and Eren (2008) reported that adding boron to layer rations caused improving egg shell quality. Mizrak et al. (2008b) reported that the supplementation of boron $(25,50$ and 75 ppm) into layer diets significantly increased the calcium accumulation in egg shell.

Boron affects the activities of at least 26 different enzymes, most of which are necessary for energy substrate metabolism (Hunt, 1998). Therefore, boron affects the Krebs cycle, the glucose- alanine cycle, and methionine metabolism all of which reduce oxidative stress and positively affect the lipid profile (Basoglu et al., 2011). Eren and Uyanik (2008) pointed out for laying hen's cholesterol levels were decreased by increasing levels of boron $(0,5,10,50,100$, 200 or $400 \mathrm{mg} / \mathrm{kg}$ ) addition to diets. Likewise, Eren et al. (2006) reported that the amount of serum cholesterol levels of quails decreased as the levels of boron (10, 60, 120 and $240 \mathrm{mg} / \mathrm{kg}$ ) increased.

It is known that semen profile is directly affected by various environmental, physical and chemical factors (Oliva et al., 2001). Moreover, Naghii and Samman (1993) noted that the mechanism of boron action may be mediated by increasing the concentration of steroid hormones such as testosterone and beta-estradiol. Whereas, inclusion of boron to bucks' rations resulted in a significant increase in sperm concentration, total sperm output, sperm motility and normal sperm (Elkomy et al., 2015).

Recent studies on the biological significance of boron to various metabolic, nutritional, hormonal, and physiological processes indicated that boron is essential for humans and animals (Nielsen, 1997; Basoglu et al., 2000, 2002; Kabu and Civelek, 2012; and Hunt, 2012). It is accepted that boron performs functions in mineral metabolism, in immune response and in the endocrine system. Unfortunately, the detailed 
mechanism by which boron functions in animals has not yet been fully described.

The present study was conducted to evaluate the effect of dietary boron on productive and reproductive performance and some blood constituents in Bandarah laying hens.

\section{MATERIALS AND METHODS}

The present experiment was carried out at El-Sabahia Poultry Research Station, Animal Production Research Institute, Agricultural Research Center, Egypt. A total of one hundred laying hens and twenty cocks of Bandarah strain at 28 weeks of age were housed in individual cages and distributed randomly in four treatment groups ( 25 females and 5 males in each one). Feed and water were supplied ad libitum throughout the experimental period which ended at 44 wks of age. Artificial lighting was used to provide birds $17 \mathrm{hrs}$ lighting daily. The basal diet (control) was formulated to meet nutrient requirements of chickens. The composition of the basal diet is given in Table (1). Birds in group1 were fed a basal diet and considered as control group, the other three groups 2, 3 and 4 were fed a basal diet supplemented with 100, 200 and $300 \mathrm{mg}$ boron/ $\mathrm{kg}$ feed respectively in the form of boric acid.

\section{Productive parameters:}

Egg weight ( $g$ ) and egg number were recorded daily. Egg mass was calculated by multiplying egg number by average egg weight per hen $(\mathrm{g} / \mathrm{h} / \mathrm{d})$. Feed conversion was calculated as the amount of feed consumed $(\mathrm{g})$ required in order to produce a unit $(\mathrm{g})$ of egg mass ( $g$ feed/g egg). Fifteen eggs from each treatment were randomly taken once every four weeks to measure egg quality according to Romanoff and Romanoff (1949):

Egg shape index $(\%)=($ width/length $) \times 100$

Eggs were individually broken out, albumen, yolk, yolk color and shell weights were measured to the nearest $0.1 \mathrm{gm}$ and their relative weights were calculated as percentage of egg weight.
Haugh units (H.U.) were calculated based upon the height of albumen determined by micrometer and egg weight according to the formula of Hough (1937):

$\mathrm{HU}=100 \log \left(\mathrm{H}+7.57-1.7 \mathrm{~W}^{0.37}\right)$

Where $\mathrm{H}=$ thick albumen height $(\mathrm{mm})$.

$\mathrm{W}=$ egg weight $(\mathrm{g})$.

Washed shells were left for $72 \mathrm{hrs}$ at environmental temperature, dried, individually weighed, and their relative weights were calculated as percentage of egg weight. Egg shell thickness was measured for three equatorial regions of 15 eggs using a manual micrometer. The quantities of crude ash in egg shells were determined by burning at $550 \mathrm{C}$ for one night in ash oven. These ashes were analyzed for boron, calcium and phosphorus using spectrophotometric method (respectively, TSE 945.04, 958.01, 982.01, AOAC, 1990).

\section{Blood constituents:}

At 44 wks of age, blood samples were randomly taken from 10 hens from each treated group in heparinized tube from the brachial wing vein. A portion of the fresh blood was used to count the white blood cells (WBCs), red blood cells (RBCs), and measure hemoglobin $(\mathrm{Hb})$ and packed cell volume (PCV). Plasma and serum were obtained from the blood samples by centrifugation for $15 \mathrm{~min}$. at $3000 \mathrm{rpm}$ and was stored at $-20{ }^{\circ} \mathrm{C}$ until the time of analysis. Plasma calcium $(\mathrm{Ca})$, phosphorus $(\mathrm{P})$, iron $(\mathrm{Fe})$, copper $(\mathrm{Cu})$, boron $(\mathrm{B})$, total protein, albumin, total lipids, cholesterol, low density lipoprotein (LDL), high density lipoprotein (HDL), glucose, alanine aminotransamenase (ALT), and asparatate aminotransamenase (AST) were determined spectrophotometrically using available commercial Kits. Serum triiodothyronine (T3) concentrations were measured using commercial ELISA kita.

\section{Semen evaluation:}

At 36 weeks of age, semen samples were collected from cocks of each treatment once weekly by abdominal massage technique. Physical properties of semen (ejaculate 
volume $\mathrm{ml}$, sperm motility $\%$, sperm abnormality $\%$ and sperm concentration) were determined. Sperm motility index (SMI) was calculated according to Howard et al. (1986):

SMI $=($ Sperm motility percentage + \{Forward progressive motilityx 20\})/2

Forward progressive motility graded by the Scale of 0 to 5 where $0=$ no forward movement, $1=$ slight movement $(1-20 \%), 2=$ undulatory movement $(20-40 \%), 3=$ progressive and slow moving (40-60\%), $4=$ progressive motility $(60-80 \%)$ and $5=$ rapid linear forward progressive (80-100) (Melrose and Laing, 1970).

\section{Fertility and Hatchability percent:}

At 38 wks of age, hens were inseminated twice a week with diluted semen (1:1) from cocks that received the same treated diets. Hatching eggs were collected daily from each group at 40, 42 and 44 wks of age. A total of 800 hatching eggs representing the four experimental dietary groups were incubated in Egyptian-made incubator at $37.8 \mathrm{C}$ and $55 \% \mid \mathrm{RH}$ during incubation and transferred to hatcher operated at $37.2{ }^{\circ} \mathrm{C}$ and $65 \%$ RH. Egg fertility and hatchability were determined.

\section{Statistical analysis:}

Data were statistically analyzed according to SAS program (SAS, 2004) using GLM Procedure. All the data were subjected to one way analysis of variance model. Mean differences were tested by Duncan's multiple range (Duncan, 1955).

\section{RESULTS AND DISCUSSION Productive performance}

Egg production, egg weight, egg mass, feed consumption and feed conversion ratio are given in Table 2.Results showed that, boron supplementation did not affect egg production, feed consumption, egg mass and feed efficiency. While, egg weight was increased by increasing boron level by 2.29 , 3.09 and $5.20 \%$ for 100,200 and $300 \mathrm{mg}$ boron, respectively over the control group but these increases were not significant. Results are in agreement with those reported by Mizrak et al. (2010) who found that, supplementation of $25-200 \mathrm{mg}$ boron/ $\mathrm{kg}$ to hens during a period of 4-64 weeks of age did not affect the productive performance of the layers. Similarly, Sizmaz et al. (2014) showed no significant effect in the egg production, feed intake and feed efficiency of laying hens fed diet added with 60 and $180 \mathrm{mg}$ boric acid $/ \mathrm{kg}$. Olgun and Bahtiyarea (2015) indicated that, egg production, egg mass, feed intake and feed conversion ratio were not affected by dietary boron at 60 and $120 \mathrm{mg}$ boron/ $\mathrm{kg}$ in the laying hens.

It was previously reported that, dietary boron up to $250 \mathrm{mg} / \mathrm{kg}$ did not have any detrimental effect on productive performance of laying hens while, $400 \mathrm{mg}$ boron $/ \mathrm{kg}$ decreased body weight gain and feed intake (Rossi et al., 1993; Wilson and Ruszler, 1996, 1998; Kurtoglu et al., 2002; and Eren et al., 2004).

Regarding the egg weight, the improvement in egg weight for treated groups in the present result is consistent with finding of Yesilbag and Eren (2008) who revealed that, the addition of boric acid (25, 50 and 100 $\mathrm{mg} / \mathrm{kg}$ ) to the diets caused a significant increase in egg weight for layers. Opposite results were found by Kucukyilmaz et al. (2014), they reported that supplemental boron (57 and $150 \mathrm{mg} / \mathrm{kg}$ ) significantly decreased the feed consumption and egg weight for laying hens.

\section{Egg quality traits}

Table 3 shows the effect of dietary boron on egg quality traits of Bandarah laying hens. Results recorded that, there was a significant $(p<0.05)$ increase in shell \% by 5.2, 5.4 and $6.8 \%$ over the control value. Likewise, shell thickness and Haugh unit \% (HU) significantly $(\mathrm{p}<0.01)$ improved for laying hens fed diet with boron by5.4, 8.1 and 8.1 $\%$ for shell thickness and 5.2, 6.5 and $12.1 \%$ for $\mathrm{HU}$ above the control value for 100, 200 and $300 \mathrm{mg}$ boron $/ \mathrm{kg}$, respectively. The Haugh unit is a known indicator of egg freshness and is related to shelf life. The improvement in HU may indicate that boron supplementation can improve egg quality by increasing its shelf life. These results are in 
agreement with Yesilbag and Eren (2008) who observed that improvement of eggshell thickness in laying hens fed diets supplemented with boric acid $(25,50$ and $100 \mathrm{mg} / \mathrm{kg}$ ). Mizrak et al. (2008a; 2010) showed a significant increase of $\mathrm{HU}$ for laying hens fed diets that included 25 and 50 $\mathrm{mg}$ boron $/ \mathrm{kg}$. While, Shape index, yolk color score, albumen $\%$ and yolk $\%$ were not affected by supplemented boron. Similar results were confirmed by Sizmaz et al. (2014).

\section{Mineral contents of the eggshell}

Data of Figure 1 illustrate that there was a significant effect $(\mathrm{p}<0.01)$ of adding boron to layer diets at different levels on calcium, phosphorus and boron contents of the eggshell. This effect was in a leveldependent manner, whereas, $\mathrm{Ca}$ accumulation in eggshell significantly increased with increasing dietary boron level. The same trend was shown with eggshell phosphorus, which showed a significant $(\mathrm{p}<0.01)$ increase by increasing boron level. These findings are confirmed with those previously reported by Mizrak et al. (2008b) who reported that the supplementation of boron to layer diets significantly increased the calcium accumulation in eggshell as compared to the control value. In addition, Mizrak and Ceylan (2008) recorded that adding organic or inorganic boron to laying hens rations (25, 50 and 75 ppm) increased $\mathrm{Ca}$ and $\mathrm{P}$ in eggshell.

With respect to boron accumulation in eggshell, it could be speculated that eggshell B significantly $(\mathrm{p}<0.01)$ increased by increasing boron level in the diets. This result was in harmony with finding of Mizrak and Ceylan (2008) who revealed that eggshell B was significant increase with increasing dietary boron.

The improvement in eggshell quality resulted in dietary boron could be attributed to increase the calcium deposition in the eggshell and effects of boron on metabolism of $\mathrm{Ca}, \mathrm{P}, \mathrm{Mg}$ and vitamin $\mathrm{D}$ (Nielsen and
Shuler, 1992; Naghii and Samman, 1993; Nielsen, 1988a).

\section{Blood parameters}

\section{Plasma minerals:}

Data of figure 2 illustrate that plasma minerals $(\mathrm{Ca}, \mathrm{P}, \mathrm{Cu}, \mathrm{Fe}$, and $\mathrm{B})$ were significantly $(\mathrm{p}<0.01)$ increased by addition boron at different levels. Whereas, plasma $\mathrm{Ca}, \mathrm{Fe}$ and $\mathrm{B}$ concentrations increased $(p<0.01)$ with the increase of boron levels. Additionally, plasma $\mathrm{P}$ and $\mathrm{Cu}$ concentrations increased resulted from supplemental boron compared to control value. The increase of these minerals in plasma may be attributed to boron can interact with the metabolism of some macroelements such as $\mathrm{Ca}, \mathrm{P}$ and $\mathrm{Mg}$, thereby modifying their concentration in the serum of chickens (Kurtoglu et al., 2001, 2005; Bozkurt et al., 2012). According to Nielsen (1988a), Boron's unique chemistry allows it to react with many other metabolites and enzymes, and thus may be capable of modifying mineral and energy metabolism in humans and animals.

These results are in corresponding with Kurtoglu et al. (2001) who reported that boron addition at level $25 \mathrm{mg} / \mathrm{kg}$ had a positive effect on plasma $\mathrm{Ca}$ and $\mathrm{P}$ of chicks. Olgun et al. (2012) concluded that the addition of boron $(60,120$ and $240 \mathrm{mg} / \mathrm{kg}$ ) to layer ration significantly increased plasma $\mathrm{B}$ and $\mathrm{Cu}$ concentrations especially with levels of 120 and $240 \mathrm{mg} / \mathrm{kg}$. Moreover, Kucukyilmaz et al. (2016) confirmed that the addition of boron to the diet resulted in significant increase in the boron concentration of serum.

\section{Hematological parameters:}

Values of Hb, RBC's, PCV\% and WBC's for Bandarah laying hens fed diet supplemented with boron are presented in Table 4. Data showed that all previous parameters were significantly increased by dietary boron. Whereas, $\mathrm{Hb}$ concentration was significantly increased by $9.3,25.6$ and $27.6 \%$ above the control group. The same trend was shown in the RBC's counts which showed a significant $(\mathrm{p}<0.01)$ increase by 
increasing boron level. The highest value of PCV was recorded for laying hens fed high level $(300 \mathrm{mg} / \mathrm{kg})$ of boron. The present results concerning the increasing of plasma $\mathrm{Fe}$ and $\mathrm{Cu}$ concentrations may be reflected on significant improving of blood picture. Similar results were confirmed by Ali et al. (2014) noticed that adding of boron to broiler diets at doses $(75,150$ and 250 $\mathrm{mg} / \mathrm{kg}$ ) increased $\mathrm{Hb}, \mathrm{PCV} \%$, RBCs and WBCs. Additionally, boron increase the response of cell membrane of blood cell to erythropoietin and this hormone synthesized in the kidney which plays an essential role in the maturation of red blood cell precursors in bone marrow (Nielsen et al., 1991).

\section{Biochemical parameters:}

Results of Table 5 indicated that plasma total protein, albumin and globulin were increased by adding boron to layer diets. Total protein and globulin were significantly increased while increase in albumin was not significant. Thus, these increases were 17.4, 17.6 and $18.2 \%$ of total protein, 7.1, 8.0 and $8.6 \%$ of albumin and $34.9,33.9$ and $34.4 \%$ of globulin concentration above the control value for 100,200 and $300 \mathrm{mg}$ boron/ $\mathrm{kg}$ diet, respectively. The same finding was found by El-Saadany et al. (2016) when they fed male chicks on 100, 200 and $300 \mathrm{mg}$ boron $/ \mathrm{kg}$ feed. Likewise, our findings were confirmed upon examination of boron on rabbits (Elkomy et al., 2015). As a result, supplemental boron had a beneficial effect on hens' health.

Data of Table 5 represent the influence of dietary boron on lipid profile (total lipids, cholesterol, HDL and LDL) for Bandarah laying hens. Whereas, plasma total lipids, cholesterol and LDL were significantly $(\mathrm{p}<0.01)$ decreased by adding boron to layer diets. While, plasma HDL was significant increased compared with control value. The lowest total lipids, cholesterol and LDL were recorded for hens fed basal diet with addition $200 \mathrm{mg}$ boron $/ \mathrm{kg}$. These findings were confirmed upon examination of boron on laying hens (Eren and Uyanik, 2008) and rabbit (Basoglu et al., 2010). Results revealed that the hypocholesterolemic due to the effect of boron may be a result of either a direct effect on the liver or an indirect effect through thyroid hormones which may affect the reactions in almost all the pathways of lipid metabolism.

Glucose concentrations for Bandarah laying hens fed different levels of boron are shown in Table 5. It can be observed from data of this table that plasma glucose concentrations were significantly $(\mathrm{p}<0.05)$ increased resulted in dietary boron compared with control value while, there were no significant differences among boron groups. The results of significant increase of plasma glucose could be attributed to increased thyroid gland activity, whereas, the T3 concentration was significantly increased with increase boron level in the current study. These results are in agreement with Hunt et al. (1994) who mentioned that supplemental dietary boron increased plasma glucose concentrations, particularly when vitamin $\mathrm{D}$ deficiency existed in chicks.

It appears from the results of Table 5 that supplemental boron significantly $(p<0.01)$ decreased liver aminotransaminase enzymes activities (AST and ALT). Thus, these decreases were $4.4,10.0$ and $9.7 \%$ of AST, 7.3, 10.0 and $9.3 \%$ of ALT activities less than the control value for 100, 200 and 300 $\mathrm{mg}$ boron $/ \mathrm{kg}$ diet, respectively. The improvement in liver function may be attributed to protective effects of the boron on normal liver metabolism (Hunt and Herbel, 1991a; and Ince et al., 2012). The present results concerning the decreasing of the serum transaminases activities are in agreement with the results obtained by Eren and Uyanik (2007) when they adding boron in layer diets. Likewise, our findings were confirmed upon examination of boron on broiler chicks (Eren et al., 2012) and rabbits (Elkomy et al., 2015).

Results concerning the effect of supplemental boron on thyroid hormone secretion (T3) concentration in laying hens 
are presented in Table 5. It could be speculated that the boron supplementation significantly $(\mathrm{p}<0.01)$ increased serum T3 concentration compared with control value and this increasing was in a level-dependent manner. These results are correspondence with Cinar et al. (2015) who stated that serum T3 and T4 activities increased with higher boron $(60 \mathrm{mg} / \mathrm{kg})$ supplementation in broiler chickens. The improvement in thyroid hormone secretion in current study may be due to the effect of boron on stimulate energy metabolism. According to Hunt (1998), boron affects the activities of at least 26 different enzymes, most of these enzymes are necessary for energy substrate metabolism.

\section{Semen traits}

Table 6 shows the effect of dietary boron on semen quality characteristics (ejaculate volume, sperm concentration, sperm motility, sperm abnormality, and sperm motility index), fertility and hatchability of eggs fertile. Boron supplementation to cocks diet significantly improved semen quality. Whereas, a significant increase $(\mathrm{p}<0.01)$ was observed in ejaculate volume by 32.3 , 35.5 and $41.9 \%$ above the control value for 100,200 and $300 \mathrm{mg}$ boron $/ \mathrm{kg}$ diet, respectively. This increase was in a leveldependent manner. The same trend was shown in the sperm concentration, sperm motility and sperm motility index. The increased sperm concentration in the boron groups was reflected on significant increase in semen ejaculate volume. According to Kamel et al. (2009), increase in ejaculate volume was necessary for sperm to provide them by nutritious elements that are needed for their live. On the other hand, the percentage of abnormal sperm was significantly decreased with increasing boron level to reach, and \% less than the control group. These results are in agreement with Elkomy et al. (2015) who concluded that adding boric acid to bucks' ration $(100,200$ and $400 \mathrm{mg} / \mathrm{kg}$ ) improved semen quality characteristics.
The improvement in semen quality reported in the present study may be attributes to the boron affects several enzymes that stimulate the spermatogenesis to produce a complete sperm. Whereas, boron affects the activities of at least 26 different enzymes, most of these enzymes are necessary for energy substrate metabolism (Hunt, 1998).

\section{Fertility and hatchability percentage}

Boron supplementation significantly $(\mathrm{p}<0.05)$ increased fertility and hatchability of fertile eggs percentage (Table 6). This increase was in a level-dependent manner. This result is in contrast with Rossi et al. (1993) who reported that fertility and hatchability were not affected when broiler breeder fed on two sources of boron at level $(0-250 \mathrm{mg} / \mathrm{kg})$. The beneficial effect of boron on fertility and hatchability in the present result may be due to the mechanism of boron action by increasing the concentration of steroid hormones such as testosterone and beta-estradiol (Naghii and Samman, 1993). Likewise, Benderdour et al. (1998) confirmed that supplemental boron caused increasing in the serum concentration of 17 beta-estradiol and testosterone. Indeed, thyroid hormones are involved in numerous physiological processes thus increase of serum T3 concentration by adding boron in the current study may be reflected on fertility.

\section{CONCLUSION}

As a result of the current study, it can be concluded that boron supplementation in layer diets had a positive effect on plasma minerals $(\mathrm{Ca}, \mathrm{P}, \mathrm{Fe}, \mathrm{Cu}$ and $\mathrm{B})$ and minerals of egg shell ( $\mathrm{Ca}, \mathrm{P}$ and $\mathrm{B})$. However, shell thickness, Haugh unit, physiological status, semen quality, fertility and hatchability were improved by adding boron at different studied level. It is suggested that up to 300 $\mathrm{mg}$ boron $/ \mathrm{kg}$ diet could be used in layer diets without any adverse effect on laying hens performance. 
Table (1): Composition* and the nutritive value of the basal diets

\begin{tabular}{|l|c|l|c|}
\hline \multicolumn{1}{|c|}{ Ingredients } & \% & \multicolumn{1}{|c|}{ Calculated Composition } & \\
\hline yellow Corn & 63.55 & Crude Protein, \% & 16.50 \\
Soybean M. (CP44\%) & 25.10 & ME, Kcal/kg & 2700 \\
Premix ** & 0.30 & Crud fiber, \% & 2.60 \\
$\mathrm{NaCl}$ & 0.40 & $\mathrm{Ca}, \%$ & 3.50 \\
$\mathrm{Di} . \mathrm{Ca}$. phosphate. & 1.45 & $\mathrm{P}(\mathrm{va}), \%$ & 0.40 \\
Limestone & 8.10 & Ly, \% & 0.89 \\
Mineral supplementations & 1.00 & Meth, \% & 0.36 \\
DL-methionine (Meth) & 0.10 & Total sulpher amino acids \% & 0.66 \\
Total & 100 & & \\
\hline
\end{tabular}

*As recommendation of Anim. Prod. Res. Inst., Agric Res. Center, Minis. of Agric., (2001). **Composition of premix in $3 \mathrm{~kg}$ is: Vit. A, 10,000,000 IU; Vit. $\mathrm{D}_{3}, 2,000,000$; Vit. E, 10,000 mg; Vit. $K_{3}, 1,000 \mathrm{mg}$; Vit. $\mathrm{B}_{1}, 1,000 \mathrm{mg}$; Vit. $\mathrm{B}_{2}, 4,000 \mathrm{mg}$; Vit. $\mathrm{B}_{6}, 1,500 \mathrm{mg}$; Vit. $\mathrm{B}_{12}, 10 \mathrm{mg}$; Niacin, 20,000 mg; Pantothenic acid, 10,000 mg; Folic acid, 1,000 mg; Biotin, $50 \mathrm{mg}$; Choline chloride, 500,000 mg; Cu, 3,000 mg; Iodine, $300 \mathrm{mg}$; Fe, 30,000 mg; Mn, 40,000 mg; Zn, 45,000 mg; Selenium, $100 \mathrm{mg}$.

Table (2): Productive performance of Bandarah laying hens fed diets supplemented with different levels of boron

\begin{tabular}{|l|c|c|c|c|c|c|}
\hline \multirow{2}{*}{\multicolumn{1}{|c|}{ Parameters }} & \multicolumn{4}{|c|}{ boron levels (mg/kg diet) } & \multirow{2}{*}{ SEM } & \multirow{2}{*}{ Sig. } \\
\cline { 2 - 5 } & $\mathbf{0}$ & $\mathbf{1 0 0}$ & $\mathbf{2 0 0}$ & $\mathbf{3 0 0}$ & & \\
\hline Egg weight (g) & 51.17 & 52.34 & 52.75 & 53.83 & 1.08 & NS \\
Egg production (\%) & 52.18 & 52.75 & 53.02 & 53.06 & 1.16 & NS \\
Egg mass (g/h/d) & 26.69 & 27.62 & 27.97 & 28.57 & 0.64 & NS \\
Feed consumption(g/h/d) & 117.37 & 117.59 & 117.54 & 117.50 & 0.32 & NS \\
Feed conversion ratio(g feed/g gegg) & 4.40 & 4.27 & 4.21 & 4.13 & 0.11 & NS \\
\hline
\end{tabular}

Sig. $=$ Significance, NS $=$ Not Significant. SEM = Standard error mean. 
Table (3): Egg quality of Bandarah laying hens fed diets supplemented with different levels of boron

\begin{tabular}{|l|c|c|c|c|c|c|}
\hline \multirow{2}{*}{\multicolumn{1}{c|}{ Parameters }} & \multicolumn{4}{|c|}{ boron levels (mg/kg diet) } & & \\
\cline { 2 - 6 } & $\mathbf{0}$ & $\mathbf{1 0 0}$ & $\mathbf{2 0 0}$ & $\mathbf{3 0 0}$ & SEM & Sig. \\
\hline Shell (\%) & $11.18^{\mathrm{b}}$ & $11.76^{\mathrm{a}}$ & $11.78^{\mathrm{a}}$ & $11.94^{\mathrm{a}}$ & 0.86 & $*$ \\
Shell thickness (mm) & $0.37^{\mathrm{b}}$ & $0.39^{\mathrm{a}}$ & $0.40^{\mathrm{a}}$ & $0.40^{\mathrm{a}}$ & 0.002 & $* *$ \\
Haugh unit \% & $80.16^{\mathrm{c}}$ & $84.31^{\mathrm{b}}$ & $85.33^{\mathrm{b}}$ & $89.89^{\mathrm{a}}$ & 1.37 & $* *$ \\
Shape index (\%) & 74.84 & 74.58 & 74.93 & 74.59 & 1.46 & $\mathrm{NS}$ \\
Yolk color score & 6.6 & 6.4 & 6.4 & 6.6 & 0.16 & $\mathrm{NS}$ \\
Albumen (\%) & 56.59 & 55.96 & 56.00 & 55.72 & 0.24 & $\mathrm{NS}$ \\
Yolk (\%) & 32.23 & 32.28 & 32.22 & 32.34 & 0.23 & $\mathrm{NS}$ \\
\hline
\end{tabular}

$\mathrm{a}, \mathrm{b}, \mathrm{c}$ Means in the same row with different superscripts, differ significantly $(\mathrm{p}<0.05)$. Sig. $=$ Significance, $*(\mathrm{p}<0.05), * *(\mathrm{p}<0.01)$. NS $=$ Not Significant. SEM $=$ Standard error mean.

Table (4): Hematological parameters of Bandarah laying hens fed diets supplemented with different levels of boron

\begin{tabular}{|l|c|c|c|c|c|c|}
\hline \multirow{2}{*}{ Parameters } & \multicolumn{4}{|c|}{ boron levels (mg/kg diet) } & \multirow{2}{*}{ Sig. } \\
\cline { 2 - 5 } & $\mathbf{0}$ & $\mathbf{1 0 0}$ & $\mathbf{2 0 0}$ & $\mathbf{3 0 0}$ & SEM & $*$ \\
\hline $\mathrm{Hb}(\mathrm{g} / \mathrm{dl})$ & $10.10^{\mathrm{c}}$ & $11.03^{\mathrm{b}}$ & $12.69^{\mathrm{a}}$ & $12.89^{\mathrm{a}}$ & 0.059 & $* *$ \\
$\mathrm{RBCs}\left(10^{6} / \mathrm{mm}^{3}\right)$ & $2.15^{\mathrm{c}}$ & $2.90^{\mathrm{b}}$ & $3.26^{\mathrm{a}}$ & $3.31^{\mathrm{a}}$ & 0.025 & $* *$ \\
$\mathrm{PCV}(\%)$ & $28.83^{\mathrm{c}}$ & $31.38^{\mathrm{b}}$ & $31.50^{\mathrm{b}}$ & $32.31^{\mathrm{a}}$ & 0.082 & $* *$ \\
$\mathrm{WBCs}\left(10^{3} / \mathrm{mm}^{3}\right)$ & $6.43^{\mathrm{b}}$ & $7.58^{\mathrm{a}}$ & $7.43^{\mathrm{a}}$ & $7.65^{\mathrm{a}}$ & 0.080 & $* *$ \\
\hline
\end{tabular}

$a, b$, c Means in the same row with different superscripts, differ significantly $(\mathrm{p}<0.05)$. Sig.= Significance, $* *(\mathrm{p}<0.01)$. SEM $=$ Standard error mean.

$\mathrm{Hb}=$ hemoglobin $; \mathrm{RBC}=$ red blood cells; $\mathrm{PCV}=$ packed cell volume; $\mathrm{WBC}=$ white blood cells . 
Table (5): Some blood constituents of Bandarah laying hens fed diets supplemented with different levels of boron

\begin{tabular}{|l|c|c|c|c|c|c|}
\hline \multirow{2}{*}{\multicolumn{1}{|c|}{ Parameters }} & \multicolumn{3}{|c|}{ boron levels (mg/kg diet) } & \multirow{2}{*}{ Sig. } \\
\cline { 2 - 5 } & $\mathbf{0}$ & $\mathbf{1 0 0}$ & $\mathbf{2 0 0}$ & $\mathbf{3 0 0}$ & SEM & \\
\hline Total protein(g/dl) & $5.17^{\mathrm{b}}$ & $6.07^{\mathrm{a}}$ & $6.08^{\mathrm{a}}$ & $6.11^{\mathrm{a}}$ & 0.03 & $* *$ \\
Albumin (g/dl) & 3.25 & 3.48 & 3.51 & 3.53 & 0.04 & NS \\
Globulin (g/dl) & $1.92^{\mathrm{b}}$ & $2.59^{\mathrm{a}}$ & $2.57^{\mathrm{a}}$ & $2.58^{\mathrm{a}}$ & 0.03 & $* *$ \\
Total lipids (mg/dl) & $423.13^{\mathrm{a}}$ & $401.18^{\mathrm{b}}$ & $381.16^{\mathrm{c}}$ & $402.18^{\mathrm{b}}$ & 1.98 & $* *$ \\
Cholesterol(mg/dl) & $160.08^{\mathrm{a}}$ & $145.94^{\mathrm{b}}$ & $140.77^{\mathrm{c}}$ & $144.63^{\mathrm{b}}$ & 1.16 & $* *$ \\
HDL(mg/dl) & $33.60^{\mathrm{c}}$ & $39.12^{\mathrm{b}}$ & $42.73^{\mathrm{a}}$ & $39.34^{\mathrm{b}}$ & 0.12 & $* *$ \\
LDL (mg/dl) & $88.35^{\mathrm{a}}$ & $84.01^{\mathrm{b}}$ & $79.96^{\mathrm{c}}$ & $83.33^{\mathrm{b}}$ & 0.18 & $* *$ \\
Glucose (mg/dl) & $163.95^{\mathrm{b}}$ & $173.92^{\mathrm{a}}$ & $174.46^{\mathrm{a}}$ & $174.76^{\mathrm{a}}$ & 0.82 & $*$ \\
AST (U/L) & $66.00^{\mathrm{a}}$ & $63.12^{\mathrm{b}}$ & $59.38^{\mathrm{c}}$ & $59.62^{\mathrm{c}}$ & 0.23 & $* *$ \\
ALT (U/L) & $29.09^{\mathrm{a}}$ & $26.97^{\mathrm{b}}$ & $26.27^{\mathrm{b}}$ & $26.38^{\mathrm{b}}$ & 0.26 & $* *$ \\
T3 (ng/ml) & $1.90^{\mathrm{d}}$ & $2.16^{\mathrm{c}}$ & $2.58^{\mathrm{b}}$ & $3.00^{\mathrm{a}}$ & 0.02 & $* *$ \\
\hline
\end{tabular}

$\mathrm{a}, \mathrm{b}, \mathrm{c}, \mathrm{d}$, Means in the same row with different superscripts, differ significantly $(\mathrm{p}<0.05)$. Sig. $=$ Significance, $*(\mathrm{p}<0.05), * *(\mathrm{p}<0.01) . \mathrm{NS}=$ Not Significant. $\mathrm{SEM}=$ Standard error mean.

HDL = High density lipoprotein; LDL= Low density lipoprotein; T3= Triiodothyronine. 
Table (6): Physical semen traits, fertility and hatchability of Bandarah cocks fed diet supplemented with different levels of boron

\begin{tabular}{|l|c|c|c|c|c|c|}
\hline \multirow{2}{*}{ Parameters } & \multicolumn{3}{|c|}{ Boron levels $(\mathrm{mg} / \mathrm{kg}$ diet $)$} & \multirow{2}{*}{ Sig } \\
\cline { 2 - 6 } Ejaculate volume (ml) & 0 & 100 & 200 & 300 & Pooled SEM & $*$ * \\
Sperm concentration $\left(10^{\%} / \mathrm{ml}\right)$ & $1.93^{\mathrm{c}}$ & $2.18^{\mathrm{b}}$ & $2.49^{\mathrm{a}}$ & $2.52^{\mathrm{a}}$ & 0.03 & $* *$ \\
Sperm motility (\%) & $89.16^{\mathrm{c}}$ & $91.00^{\mathrm{b}}$ & $94.04^{\mathrm{a}}$ & $94.86^{\mathrm{a}}$ & 0.13 & $*$ \\
Sperm abnormality (\%) & $11.74^{\mathrm{a}}$ & $10.06^{\mathrm{b}}$ & $8.76^{\mathrm{c}}$ & $8.30^{\mathrm{c}}$ & 0.11 & $* *$ \\
Sperm motility index & $94.50^{\mathrm{c}}$ & $95.51^{\mathrm{b}}$ & $97.04^{\mathrm{a}}$ & $97.44^{\mathrm{a}}$ & 0.1 & $*$ \\
Fertility (\%) & $87.53^{\mathrm{d}}$ & $90.27^{\mathrm{c}}$ & $91.59^{\mathrm{b}}$ & $94.90^{\mathrm{a}}$ & 0.56 & $*$ \\
Hatchability of fertile eggs $\%$ & $86.41^{\mathrm{d}}$ & $89.33^{\mathrm{c}}$ & $90.81^{\mathrm{b}}$ & $92.40^{\mathrm{a}}$ & 0.24 & $*$ \\
\hline
\end{tabular}

$\mathrm{a}, \mathrm{b}, \mathrm{c}, \mathrm{d}$ Means in the same row with different superscripts, differ significantly $(\mathrm{p}<0.05)$. Sig. = Significance, $*(\mathrm{p}<0.05), * *(\mathrm{p}<0.01)$. SEM $=$ Standard error mean. 
Fig. 1: Eggshell calcium, phosphorus and boron of Bandarah laying hens fed diet supplemented with different levels of boron

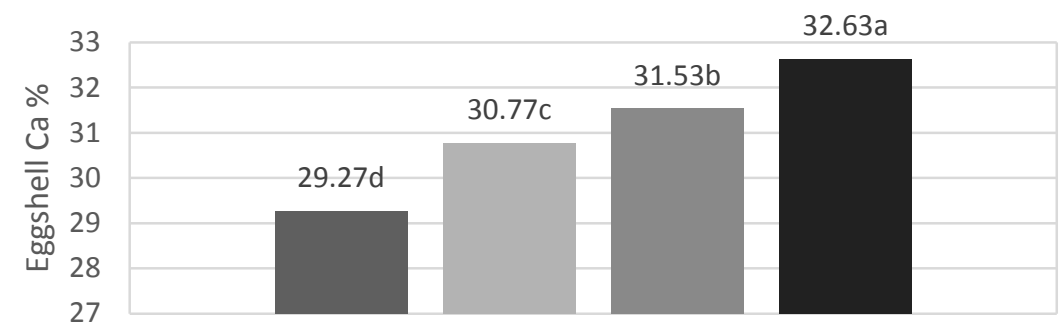

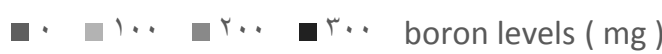

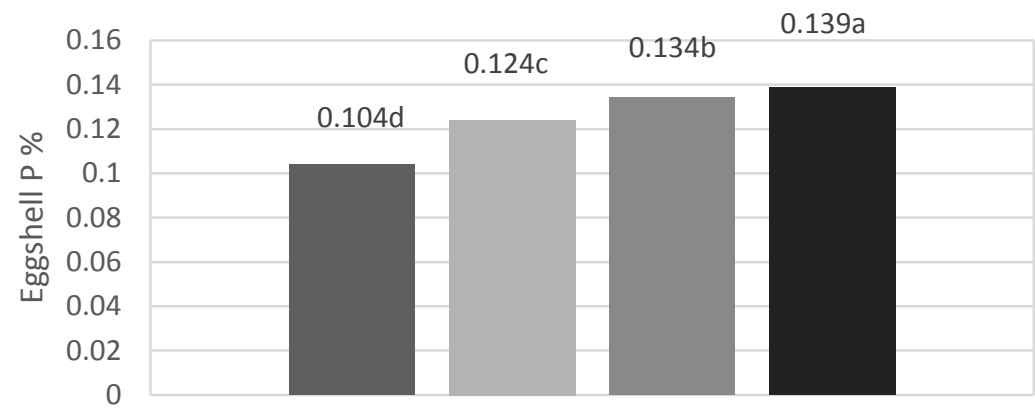

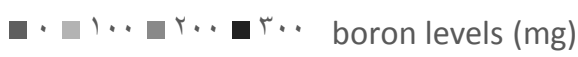

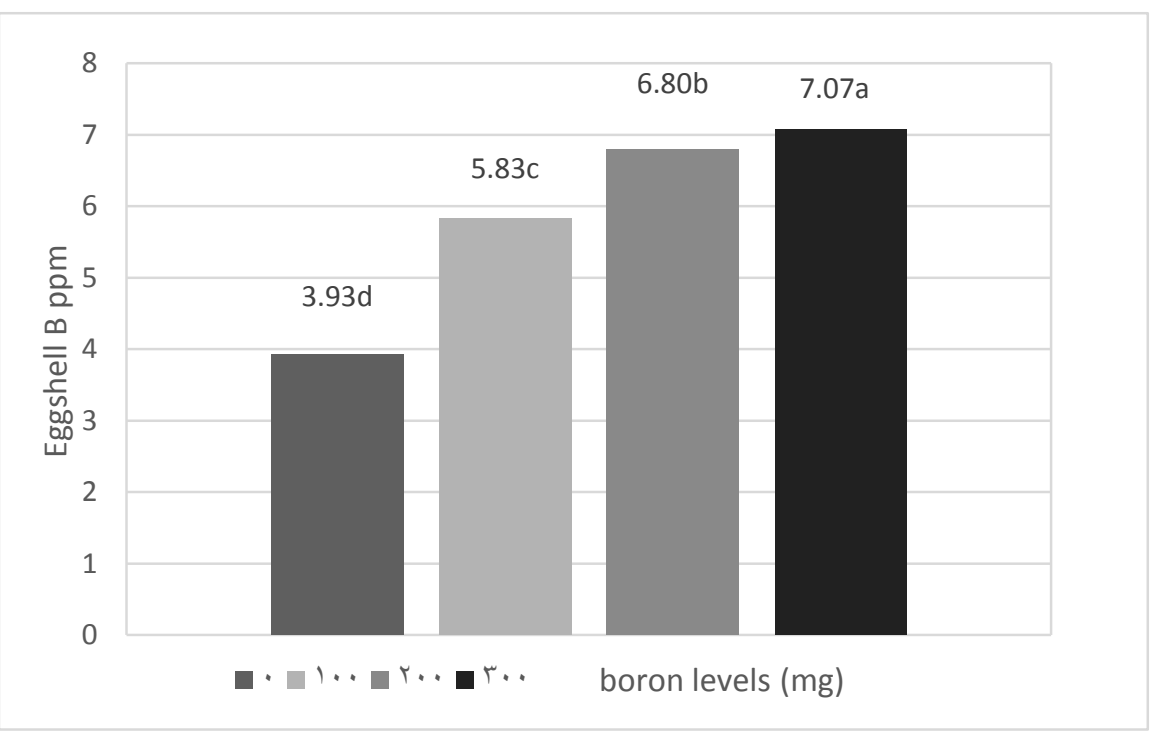


Fig. 2: Plasma minerals of Bandarah laying hens fed diet supplemented with different levels of boron
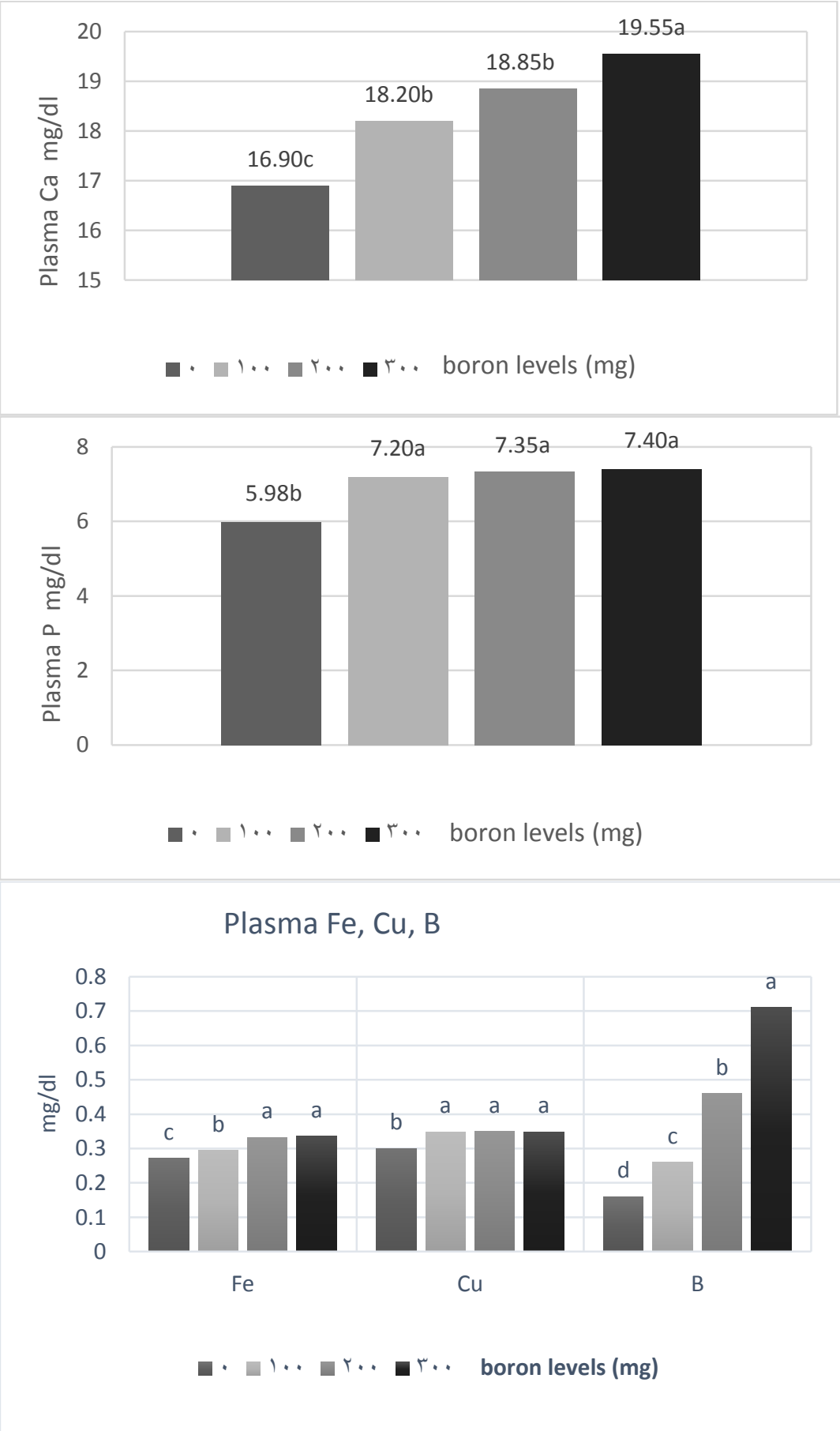


\section{REFERENCES}

Ali, B. H.; Hmud, M. F.; and Ali, E. J., 2014. Effect of boron on broiler productive traits and immune response of Newcastle disease vaccine. Al-Anbar J. Vet. Sci., 7(1): 1-11.

AOAC, 1990. Official Methods of Analysis $\left(15^{\text {th }}\right.$ ed.), Association of official analytical chemists, Washington, DC.

Basoglu, A.; Baspinar, N.; Ozturk, A. S.; and Akalin, P. P., 2011. Effects of longterm boron administration on highenergy diet-induced obesity in rabbits: NMR-basedmetabonomic evaluation. J. Anim. Vet. Adv., 10(12): 1512-1515.

Basoglu, A.; Sevinç, M.; Birdane, F. M.; and Boydak, M., 2002. Efficacy of sodium borate in the prevention of fatty liver in dairy cows. J. Vet. Int. Med., 16: 732-735.

Basoglu, A.; Sevinc, M.; Guzelbektas, H.; and Civelek, T., 2000. Effect of borax on lipid profile in dogs. Online J. Vet. Res., 4(6): 153-156.

Basoglu, A.; Baspinar, N.; Ozturk, S. A.; and Akalin, P. P., 2010. Effects of boron administration on hepatic steatosis, hematological and biochemical profiles in obese rabbits. Trace Elements Elecrolytes, 27: 225-231.

Benderdour, M.; Bui-Van, T.; Dicko, A.; and Belleville, F., 1998. In Vivo and in vetro effects of boron and boronated compounds. J. Trace Elem. Med. Biol., 12(1): 2-7.

Bozkurt, M.; Kucukilmaz, K.; Catli, A. U.; Cinar, M.; Cabuk, M.; and Bintas, E., 2012. Effects of boron supplementation to diets deficient in calcium and phosphorus on performance with some serum, bone and fecal characteristics of broiler chickens. Asian Aust. J. Anim. Sci., 25: 248-255.

Cinar, M.; Kucukyilmaz, K.; Bozkurt, M.; Catli, A. U.; Bintas, E.; Aksit, H.; Konak, R.; Yamaner, C.; and Seyrek, K., 2015. Effects of dietary boron and phytase supplementation on growth performance and mineral profile of broiler chickens fed on diets adequate or deficient in calcium and phosphorus. Brit. Poult. Sci., 56: 576-589.

Cufadar, Y.; Olgun, O.; and Bahtiyarca, Y., 2011. Effects of different sources of boron supplementation to diet on egg shell quality and bone characteristics in laying hens. Archiva Zootechnica, 14(3): 37-42.

Devirian, T. A.; and Volpe, S. L., 2003. The physiological effects of dietary boron. Crit. Rev. Food Sci., 43: 219-231.

Duncan, D. B., 1955. Multiple Rang and Multiple F Test. Biometrics, 11: 42.

Elkomy, A. E.; Abd El-hady, A. M.; and Elghalid, O. A., 2015. Dietary boron supplementation and its impact on semen characteristics and physiological status of adult male rabbits. Asian J. Poult. Sci., 9(2): 85-96.

El-Saadany, S. Amina; Amal, M. ElBarbary; and Effat, Y. Shreif, 2016. The influence ofdietary boron supplementation on performance and some physiological parameters in Bandarah chikens 1-Growing period. Egypt. Poult. Sci., 36: 1131-1146.

Eren, M.; Uyanik, F.; and Kucukersan, S., 2004. The influence of dietary boron supplementation on egg quality and serum calcium, inorganic phosphorus, magnesium levels and alkaline phosphatase activity in laying hens. Res. Vet. Sci., 76: 203-210.

Eren, M.; and Uyanik, F., 2008. Influence of dietary boron supplementation on some serum metabolites and egg-yolk cholesterol in laying hens. Acta Veterinaria Hungarica, 55: 29-39.

Eren, M.; Kocaoglu Guclu, B.; Uyanik, F.; and Karabulut, N., 2006. The effects of dietboron supplementation on performance, carcass composition and serum lipids in Japanese quails. Java, 5(12): 1105-1108.

Eren, M.; Uyanik, F.; Guclu, B. K.; and Atasever, A., 2012. The influence of dietary boron supplementation on performance, some biochemical parameters and organs in broilers. Asian J. Anim. Vet. Adv., 7: 1079-1089. 
Haugh, R. R., 1937. The Haugh unit for measuring egg quality. US Egg Poult. Mag., 43: 552- 555.

Howard, J. G.; Bush, M.; and Wildt, D. E., 1986. Semen collection, analysis and cryopreservation in nondomestic mammals. pp: 1047-1053 in: current Therapy in Theriogenology. D. A. Morrow, ed. W. B. Saunders, Philadelphia, PA.

Howe, P. D., 1998. A review of boron effects in the environment. Biol. Trace Elem. Res., 66: 153-166.

Hunt, C. D., 2012. Dietary boron: progress in establishing essential role in human physiology. J. Trace Elem. Med. Biol., 26: 157-160.

Hunt, C. D.; and Herbel, J. L., 1991. Boron affects energy metabolism in the streptozotocin- injected, nutriture on indices of energy substrate utilization and mineral metabolism in the chick. J. Bone Miner. Res., 9: 171-181.

Hunt, C. D., 1994. The biochemical effects of physiologic amounts of dietary boron in animal nutrition models. Environ. Health Perspect., 102(7): 35-42.

Hunt, C. D., 1998. One possible role of dietary boron in higher animals and humans. Biol. Trace Elem. Res., 66: 205-225.

Hunt, C. D.; Herbel, J. L.; and Idso, J. P., 1994. Dietary boron modifies the effects of vitamin $\mathrm{D}$, nutritive on indices of energy substrate utilization and mineral metabolism in the chick. J. Bone Miner. Res., 9: 171-181.

Ince, S.; Keles, H.; Erdogan, M.; Hazman, O.; and Kucukkurt, I., 2012. Protective effect of boric acid against carbon tetrachloride-induced hepatotoxicity in mice. Drug Chem. Toxicol., 10.3109/01480545.2011.607825.

Kabu, M.; and Civelek, T., 2012. Effects of propylene glycol, methionine and sodium borate on metabolic profi le in dairy cattle during periparturient period. Revue Méd. Vét., 163(8-9): 419-430.

Kamel, K. I.; Elkomy, A. E.; and ElSebeiy, M. S., 2009. The androgenic action ofgibberellic acid (GA3) on reproductive performance of New Zealand white rabbit bucks. World J. Agric. Sci., 5: 40-4.

Kılıç, A. M.; Kılıç, Ö.; Andaç, İ.; and Çelik, A. G., 2009. Boron mining in Turkey, the marketing situation and the economical importance of Boron in the World IV International boron symposium, Eskişehir-TURKEY, 15-17 Oct.

Kucukilmaz, K.; Bozkurt, M.; Cinar, M.; and Tuzun, A. E., 2016. Evaluation of the boron and phytase, alone or in combination in broiler diets. J. Poult. Sci., Article ID: 0150181.

Kucukyilmaz, K.; Erkek, R.; and Bozkurt, M., 2014. The effects of boron supplementation of layer diets varying in calcium and phosphorus concentrations on performance, egg quality, bone strength and mineral constituents of serum, bone and feces. Br. Poult. Sci., 55: 804-816.

Kurtoglu, F.; Kurtoglu, V.; Celik-Kececi, T.; and Nizamlioglu, M., 2005. Effects of dietary boron supplementation on some biochemical parameters, peripheral blood lymphocyte, splenic plasma cell counts and bone characteristics of broiler chicks fed with adequate inadequate vitamin D3 containing diet. Br. Poult. Sci., 46(1): 87-96.

Kurtoglu, V.; Kurtoglu, F.; and Coskun, B., 2001. Effects of boron supplementation of adequate and inadequate vitamin D3containing diet on performance and serum biochemical character of broiler chickens. Res. Vet. Sci., 71: 183-187.

Kurtoglu, V.; Kurtoglu, F.; Coskun, B.; Seker, E.; Balevi, T.; and Cetingui, I. S., 2002. Effects of boron supplementation on performance and some serum biochemical parameters in laying hens. Rev. Med. Vet., 153(12): 823-828

McDowell, L. R., 1992. Minerals in animal and human nutrition. Academic Press Inc., London, pp: 368-370.

Melrose, D. R.; and Laing, 1970. Fertility and infertility in the domestic animals. $2^{\text {nd }}$ 
edition Baillere Tindall and Cassell, London.

Miljkovic, D.; Natash, M.; and Mark, M. F., 2004. Up-regulatory impact of boron on vitamin $D$ function- dose it reflect inhibition of 24-hydroxylase. Med. Hypotheses., 63: 1054-1056.

Mizrak, C.; and Ceylan, N., 2008. Effects of organic boron supplementation into layer breeder diets on egg quality. International Egg Symposium the Return of the Good egg. Istanbul. S: 176-186.

Mizrak, C.; Yenice, E.; Can, M.; Yildirim, U.; and Atik, Z., 2010. Effects of dietary boron on performance, egg production, egg quality and some bone parameters in layer hens. S. Afr. J. Anim. Sci., 40(3): 257-264.

Mizrak, C.; Yenice, E.; Can, M.; Yildirim, U. and Atik, Z., 2008a. Yumurta tavugu karma yemlerine farkli duzeylerde bor ilavesinin performans, yumurta kalitesi ve kemik gelisimi uzerine etkileri, 2. Ulusal Bor Calistayi, 17-18 Nisan 2008, ankara, 605-612.

Mizrak, C.; Yenice, E.; Can, M.; Yildirim, U. and Atik, Z., $2008 b$. Yumurta tavugu karmayemlerine farkli duzeylerde bor ilavesinin performans, kemik gelisimi, bazi kan ve stress parametreleri ve yumurta kolesterol icerigi uzerine etkilerininbelirlenmesi, Ulusal Bor Arastirma Enstitusu Proje No: 2006-47-G13-13, Kesin Rapor, Basilmamis.

Naghii, M. R.; and Samman, S., 1993. The role of boron in nutrition and metabolism. Prog. Food Nutr. Sci., 17: 331-349.

Nielsen, F. H., 1988a. Boron-an overlooked element of potential nutritional importance. Nutr. Today (Jan/Feb), 4-7.

Nielsen, F. H., 1997. Boron in human and animal nutrition. Plant Soil, 193: 199208.

Nielsen, F. H.; and Shuler, T. R., 1992. Studies of the interaction between boron and calcium, and its modification by magnesium and potassium, in rats. Effects on growth. Blood variables and bone mineral composition. Bio. Trace Elem. Res., 35: 225-237.

Nielsen, F. H.; Mullen, L. M.; and Nielsen, E. J., 1991. Dietary boron affects blood cell counts and hemoglobin concentration in humans. J. Trace Elem. In Exp. Med., 4: 211-223.

Olgun, O.; and Bahtiyarea, Y., 2015. Effects of dietary cadmium and boron supplementations of bone in laying hens. Bio. Trace Elem. Res., 167: 56-62.

Olgun, O.; Yazgan, O.; and Cufadar, Y., 2012. Effects of boron and copper dietary supplementation in laying hens on egg shell quality, plasma and tibia mineral concentration and bone biomechanical properties. Rev. Med. Vet., 163(7): 335342.

Oliva, A.; Spira, A.; and Multigner, L., 2001. Contribution of environmental factors to the risk of male infertility. Hum. Reprod, 16: 1768-1776.

Qin, X.; and Klandorf, H., 1991. Effects of dietary boron supplementation on egg 70: production, shell quality and calcium metabolism in aged broiler hens. Poult. Sci., 2131-2138.

Romanoff, A. L.; and Romanoff, A. J., 1949. In "The avian egg John Wily and Sons; Inc., New York, U. S. A.

Rossi, A. F.; Miles, R. D.; Bootwalla, S. M.; Wilson, H. R.; and Eldred, A. R., 1993. The effect of feeding two sources of boron on broiler breeder performance. Poult. Sci. Association, 72(10): 19311934.

Samman, S.; Naghii, M. R.; Lyons Wall, P. M.; and Verus, A. P., 1998. The nutritional and metabolic effects of Boron in humans and animals. Biol. Trace Elem. Res., 66: 227-235.

SAS, 2004. SAS/STAT User's Guide Version 9.1.SAS Inc., Cary, NC.

Sizmaz, O.; Yildiz, G.; and Koksal, B. H., 2014. Effects of single or combined dietary and supplementation of boric acid and plant extract mixture on egg production, egg quality and blood 
cholesterolemia in laying hens. Kafkas Univ. Vet. Fak. Derg, 20: 599-604.

WHO, (World Health Organization), 1998. Environmental health criteria 204: boron. International programme on chemical safety, Geneva, Switzerland. ISBN 924157204 3, pp: 105-106.

Wilson, J. H.; and Ruszler, P. L., 1996. Effects of dietary boron supplementation on laying hens. Br. Poult. Sci., 37: 723-729.
Wilson, J. H.; and Ruszler, P. L., 1998. Long term effects of boron on layer bone strength and production parameters. Br. Poult. Sic., 39: 11-15.

Yesilbag, D.; and Eren, M., 2008. Effects of dietary boric acid supplementation on performance, eggshell quality and some serum parameters in aged laying hens. Turk. J. Vet. Anim. Sci., 32(2): 113-117. 


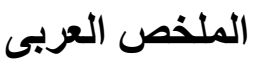

\section{تأثير إضافة البورون على الأداء وبعض القياسات الفسيولوجية فى دجاج البندرة

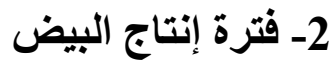

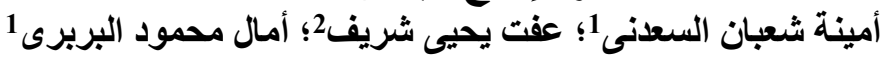

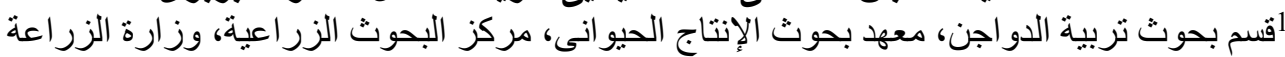

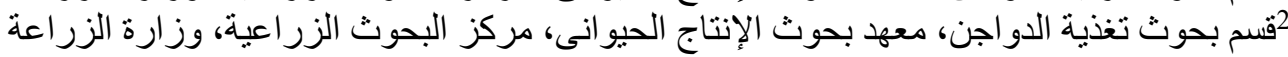

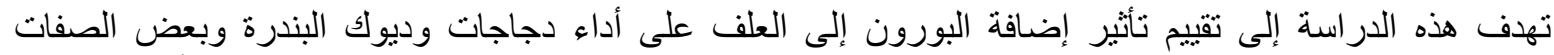

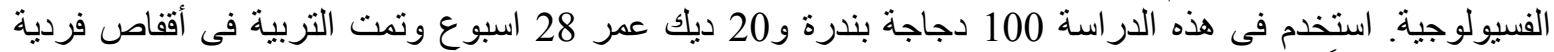

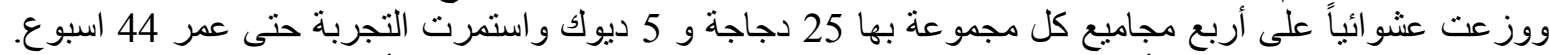

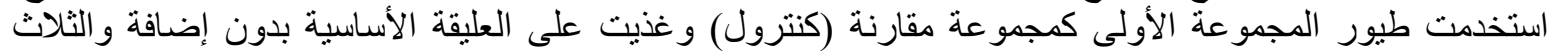

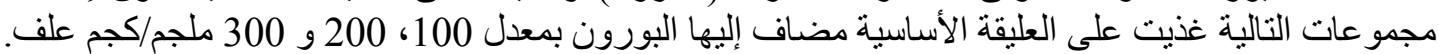

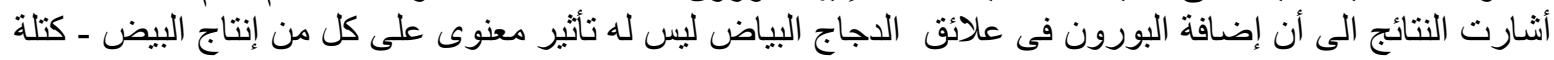

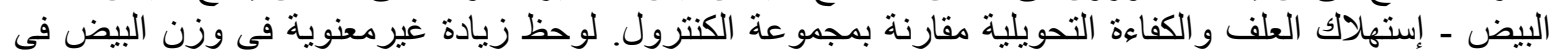

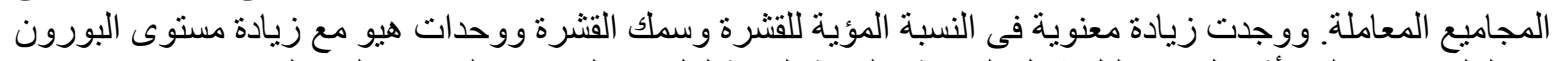

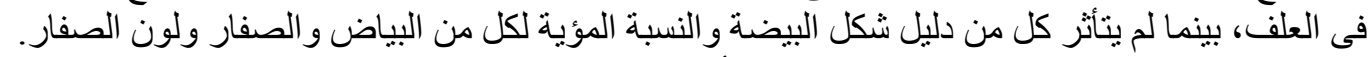

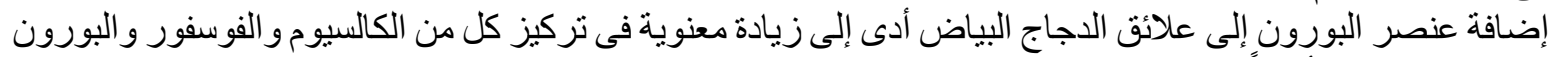

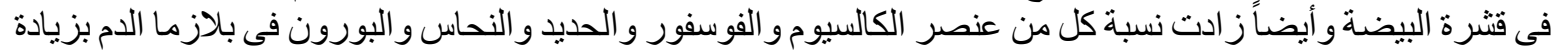

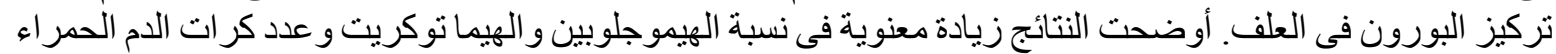

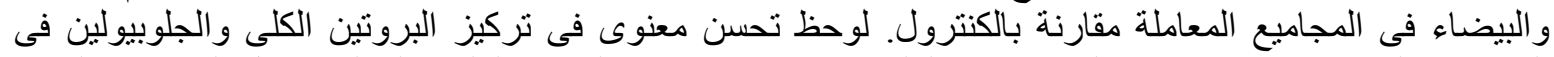

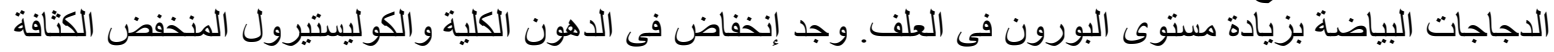

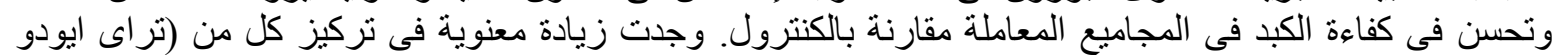

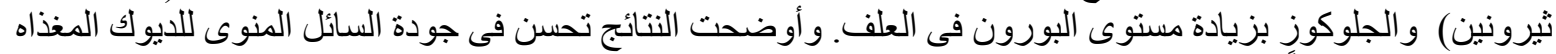

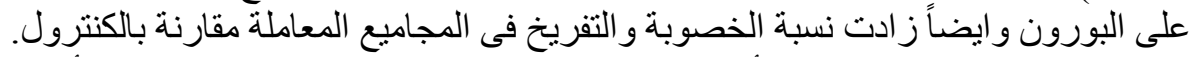

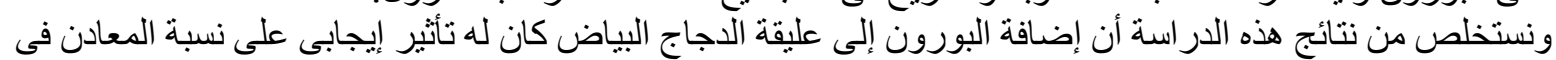

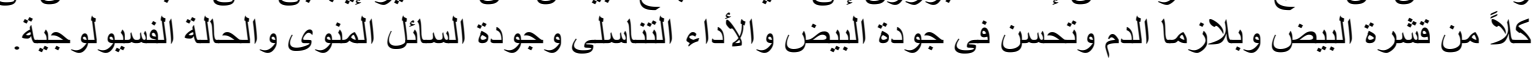

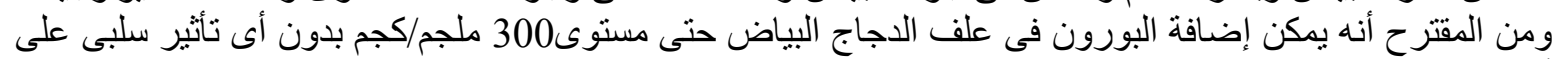

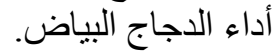

